\title{
NEVIZUÁLNE SVETELNÉ PROSTREDIE V BUDOVÁCH
}

\author{
NON-VISUAL LIGHTING ENVIRONMENT IN BUILDINGS
}

\author{
Tomáš Josai ${ }^{*}, 1$
}

"tomas.josai@stuba.sk

${ }^{1}$ Slovenská technická univerzita v Bratislave, Stavebná fakulta, Radlinského 11, 81005 Bratislava

\begin{abstract}
Abstrakt
Denné svetlo zohráva významnú úlohu pri dosahovaní úspor energie a vizuálneho pohodlia v budovách. Je v súlade s l’udskými cirkadiánnymi rytmami a umožňuje najlepšie vizuálne podmienky v pracovnom prostredí a v obytných budovách. Vzhl'adom na dynamiku života v súčasnej modernej spoločnosti l'udia trávia v interiéroch stále viac času. V dôsledku toho sa vystavujeme čoraz menej času priamemu dennému svetlu. Táto skutočnost' zvyšuje dôležitost' vhodne navrhnutého vnútorného svetelného prostredia. Rôznorodost' geometrických vlastností priestoru, ale aj optických vlastnosti stavebných materiálov výrazne komplikuje zjednodušený pohl'ad na hodnotenie cirkadiánneho potenciálu v budovách. Tento fakt poukazuje na skutočnost', že nielen kvantitu, ale aj kvalitu (t.j. spektrálne zloženie svetla) vnútorného svetelného prostredia je potrebné vhodne riešit'.
\end{abstract}

\section{Klíčová slova}

Nevizuálne efekty svetla, ekvivalentná melanopická osvetlenost', cirkadiánny stimul, cirkadiánne svetlo

\begin{abstract}
Daylight plays an important role in achieving energy savings and visual comfort in buildings. It conforms to human circadian rhythms and provides the best visual conditions in the work environment and residential buildings. Due to the dynamics of life in today's modern society, people are spending more and more time indoors. As a result, we are exposed to less and less time directly in daylight. This is true depending on the appropriateness of the indoor lighting environment. The diversity of geometric properties of the space, but also the optical properties of building materials significantly complicate the simplified view of the evaluation of the circadian potential in buildings. This fact points to the fact that not only the quantity but also the quality (i.e., colour spectrum of light) of the indoor light environment needs to be properly addressed.
\end{abstract}

\section{Key words}

Non-visual light effects, equivalent melanopic illuminance, circadian stimulus, circadian light

\section{1 ÚVOD}

V súčasnej dobe sú nevizuálne efekty svetla na človeka čoraz viac rozoberanou témou. Rôznorodost' geometrických vlastností priestoru, ale aj optických vlastnosti stavebných materiálov výrazne komplikuje zjednodušený pohl'ad na hodnotenie cirkadiánneho potenciálu v budovách [1]. Podl’a súčasných noriem a legislatívy v Slovenskej republike stále absentuje jednoznačný pohl'ad na implementovanie výskumov v oblasti melanopického svetla do právnych predpisov.

Svetlo vplýva nielen na vizuálne, ale aj nevizuálne reakcie l’udského tela, pomocou osobitnej nevizuálnej dráhy v mozgu prepojenou s vnútorne fotocitlivými gangliovými bunkami sietnice oka (Intrinsically photosensitive retinal ganglion cells - ipRGC) [2]. Na rozdiel od maximálnej citlivosti vizuálneho systému pri $555 \mathrm{~mm}$ bolo stanovené, že nevizuálny systém má maximálnu citlivost' okolo $480 \mathrm{~mm}$, v oblasti modrého a zeleného svetla [3], [4] - Obr. 1. Bolo zistené, že ak na človeka pôsobí vysoká úroveň osvetlenosti, najmä v oblasti modrého, zeleného ale aj širokospektrálneho svetla, tak spôsobuje zvýšené potlačenie melatonínu, ktorý indukuje cirkadiánne fázové posuny [5]. L'udský denný cyklus je synchronizovaný s 24 hodinovým astronomickým cyklom, ktorý sa neustále resetuje, ak je človek vystavený dennému svetlu [6]. Je potrebné však podotknút', že nevizuálne reakcie na svetlo nezávisia výlučne len od intenzity a spektrálneho zloženia svetla, ale aj od jeho časových charakteristík a dížky pôsobenia na l'udský organizmus [7]. Asynchronicita vnútorných l'udských hodín, môže viest' k mnohým zdravotným problémom, ako napr. poruchy spánku, cukrovka, kardiovaskurálne ochorenia, dokonca aj rakovina 
[8]. Svetlo neovplyvňuje iba priamy fyziologický stav človeka, ale má vplyv aj psychologické aspekty, ako sú nálada, bdelost', depresia a iné [9], [10].

\section{METODIKY MERANIA NEVIZUÁLNEHO PÔSOBENIA SVETLA}

Vzhl’adom na to, že reakcie l’udského vizuálneho a nevizuálneho systému sa líšia, bolo potrebné navrhnút' spôsoby ako kvantifikovat' nevizuálne efekty svetla. Viaceré metriky boli navrhnuté na základe potlačenia akčného spektra melatonínu [11]. V odbornej literatúre sú najčastejšie uvádzané ekvivalentné alfa-opické luxy a cirkadiánne stimuly.

Ekvivalentné alfa-opické luxy (alfa je uvažovaný fotopigment) fungujú na takom princípe, že dopadajúce žiarenie vnímané okom sa vynásobí krivkou odozvy daného fotopigmentu. Kedže v prípade nevizuálneho systému je stredobodom pozornosti sekrécia melatonínu, tak nevizuálny efekt svetla je vyjadrený ekvivalentným melanopickým luxom (EML) [12]. Takúto metodiku odporúča použivat’ aj Medzinárodná komisia pre osvetlenie (CIE) a rovnako aj certifikačný štandard budov WELL [13]. Vzt'ahy (1) a (2) pre výpočet fotopickej a ekvivalentnej melanopickej osvetlenosti sú nasledovné:

$$
\begin{gathered}
E_{\mathrm{v}}=683 \int P(\lambda) \cdot V(\lambda) \mathrm{d} \lambda \\
E_{\mathrm{m}}=4557 \int P(\lambda) \cdot s_{\mathrm{m}}(\lambda) \mathrm{d} \lambda
\end{gathered}
$$

kde Em je ekvivalentná melanopická osvetlenost' [1x], Ev fotopická osvetlenost' $[1 x], V(\lambda)$ funkcia fotopickej spektrálnej citlivosti l'udského oka s max. pri $555 \mathrm{~nm}[-], \operatorname{sm}(\lambda)$ funkcia melanopickej spektrálnej citlivosti l’udského oka s max. pri $490 \mathrm{~nm}$ [-] (podl'a CIE), $\mathrm{P}(\lambda)$ spektrálna ožiarenost' [W/m².nm] [14].

\section{Vizuálny systém}

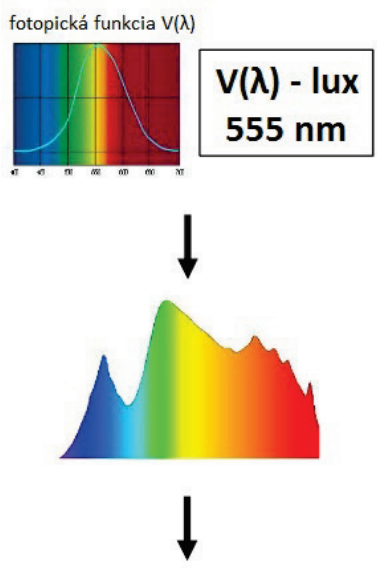

spektrum x funkcia $V(\lambda)$

fotopický lux

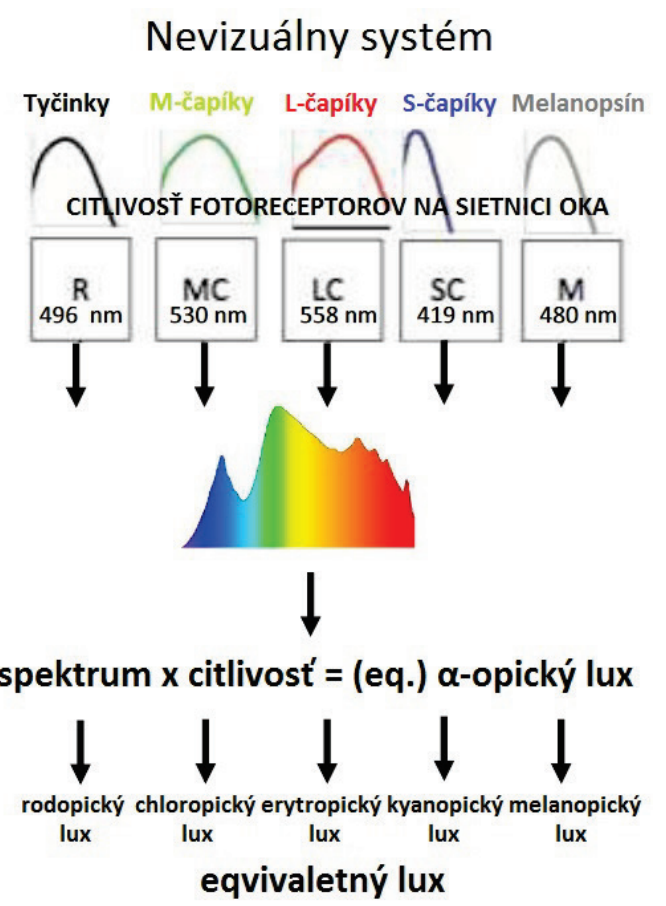

Obr. 1 Kvantifikácia svetla pomocou piatich fotoreceptorov [15]. 
Druhá metrika je navrhnutá na základe cirkadiánnych stimulov (CS) alebo na základe cirkadiánneho svetla (CLA) [16]. Melanopická citlivost' je upravená podl'a spektrálnej priepustnosti očných šošoviek pre modro-žltú farbu v dôsledku účasti iných fotoreceptorov. Je normalizovaná tak, aby osvetlenost' 1000 lx pri CCT (náhradná teplota chromatickosti, ang. color temperature) $2856 \mathrm{~K}$ zodpovedala 1000 CLA. Cirkadiánny stimul predstavuje nočné potlačenie melatonínu vyjadrené ako pomer vypočítaný na základe CLA, kde CS rovný 0,3 zodpovedá približne 275 CLA a spôsobuje 30\% supresiu melatonínu v noci [16], [17] - Obr. 2. Úroveň CS rovná alebo vyššia ako 0,3 bola pri niekol'kých uskutočnených štúdiách [18], [19] vyhlásená ako hranica na zníženie ospalosti, zvýšenie bdelosti a výkonnosti zamestnancov na pracovisku. Je potreba však podotknút', že definícia CS nezohl'adňuje časový vplyv pôsobenia svetla na zrenicu oka, ktorý pri priaznivom pôsobení, môže skresl'ovat' celkový CS.

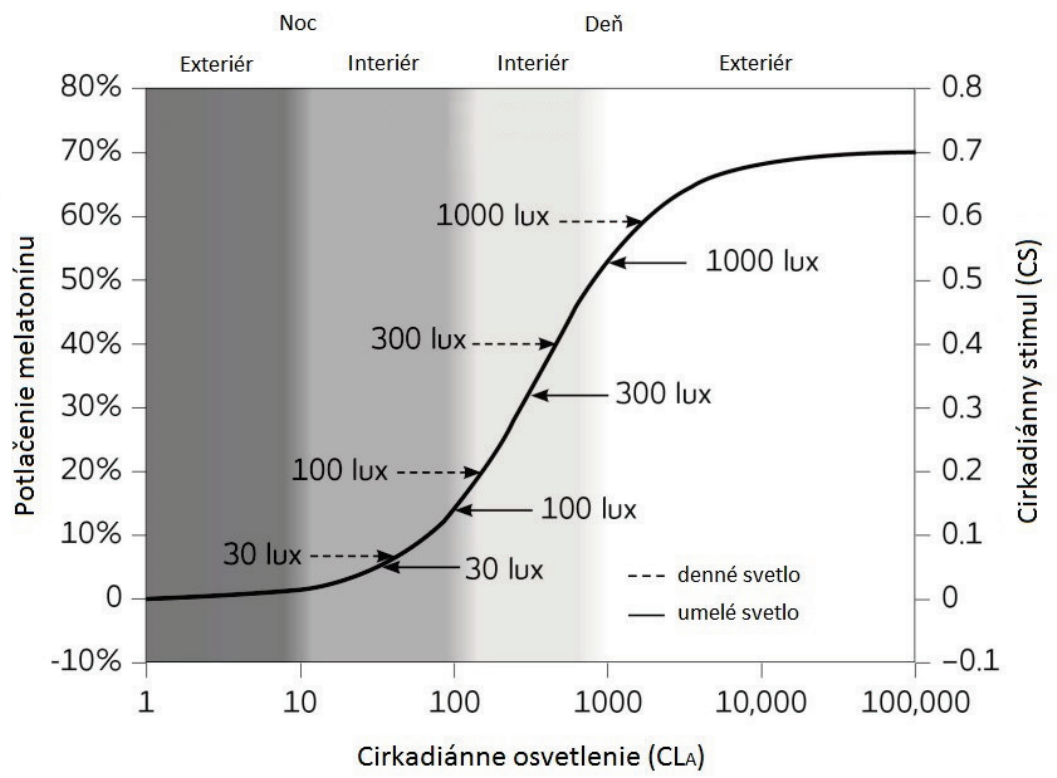

Obr. 2 Vplyv osvetlenia na potlačenie melatonínu [1].

\section{NEVIZUÁLNE SVETELNÉ PROSTREDIE BUDOV}

Vzhl’adom na dynamiku života $\mathrm{v}$ súčasnej modernej spoločnosti l'udia trávia $\mathrm{v}$ interiéroch stále viac času. V dôsledku toho sa vystavujeme čoraz menej času priamemu dennému svetlu. Táto skutočnost' zvyšuje dôležitost' vhodne navrhnutého vnútorného svetelného prostredia, ktorého význam je obzvlášt' dôležitý pre l'udí s rôznymi zdravotnými problémami [20]. Takéto skupiny l'udí sa vyznačujú odlišnou výškou a tiež smerom pohl’adu pozorovatel'a, najmä ak väčšinu času trávia na lôžku. Ďalšou zranitel'nou skupinou l'udí je staršia populácia, ktorá kvôli zožltnutiu očnej šošovky dostáva menej modrého svetla [21]. Štúdia [22], ktorá sa venovala špecifikám takýchto prostredí ako v prípade geriatrického zariadenia dokázala, že prítomnost' vyšších dávok denného svetla znamenala vyšší cirkadiánny potenciál ako pri porovnatel'ných dávkach osvetlenia, ktoré bolo dosiahnuté umelým osvetlením. Tento fakt poukazuje na skutočnost', že nielen kvantitu, ale aj kvalitu (t.j. spektrálne zloženie) vnútorného svetelného prostredia je potrebné vhodne riešit'.Zmenou farby steny a/ alebo zdroja svetla je možné dosiahnut' podstatne odlišné rohovkové alfa-opické osvetlenie, vizuálny komfort a aj spotrebu elektrickej energie z osvetlenia. Povrchy s rovnakou vizuálne váženou odrazivost'ou môžu v skutočnosti vyvolávat' nevizuálne potenciály, napr. ak by miestnost's modrými a miestnost' červenými stenami mali rovnakú vizuálnu odrazivost', tak v miestnosti s modrými stenami by bol výrazne vyšší melanopický potenciál ako v miestnosti s červenými stenami [23]. V prípade, ak by sa uvažovalo len s odrazeným komponentom denného svetla, tak dominantnú úlohu v miestnosti pre CS by zohrávali iba nepriehl'adné povrchy. Samozrejme porovnatel'ný vplyv na zloženie svetla v miestnosti má aj spektrálna priepustnost’ zasklenia. Najvyššie nevizuálne potenciály sú zaznamenané pri 
kombináciách dvojskiel a stien sfarbených na modro. Naopak, pre bronzovo tónované zasklenia a steny natreté oranžovou farbou boli zaznamenané najvyššie nevizuálne potenciály [24].

Celkové cirkadiánne charakteristiky svetelného prostredia môžu byt' tiež ovplyvnené pomerom okna k stene (ang. WWR- window to wall ratio), aplikáciou tieniaceho zariadenia a úpravou smeru pohl'adu pozorovatel'a [20], [25]. Uvedené skutočnosti poukazujú na to, že na výsledný cirkadiánny potenciál vplýva viacero faktorov, ako je napr. vel'kost' miestnosti (výška, šírka a híbka), materiál stien (nepriesvitných povrchov vo všeobecnosti) a okna, orientácia pohl'adu, pomer okna k stene.

\section{VPLYV GEOMETRICKÝCH A OPTICKÝCH VLASTNOSTÍ MIESTNOSTI}

Jedna z najnovších štúdií [26], ktorá hodnotila súčasne účinky viacerých geometrických a optických parametrov miestnosti ukázala, že okno ako stavebný prvok má zo všetkých stavebných konštrukcií najvýznamnejší vplyv na vizuálne a nevizuálne podmienky vnútorného prostredia budov. Táto štúdia bola vytvorená na základe parametrického simulačného modelu, kde sa sledovali tieto parametre: pomer okna k stene WWR a vizuálna priepustnost' zasklenia $\tau \mathrm{v}$. Geometrický model miestnosti bol vytvorený pomoc programu Rhinoceros 6 [27], pričom samotná simulácia spektrálneho svetelného prostredia prebiehala v programe Alfa [28] - Obr. 3. Modelová miestnost' má funkciu kancelárie, ktorej sa počas simulácie menili pôdorysné rozmery, pričom výška miestnosti bola konštantná.

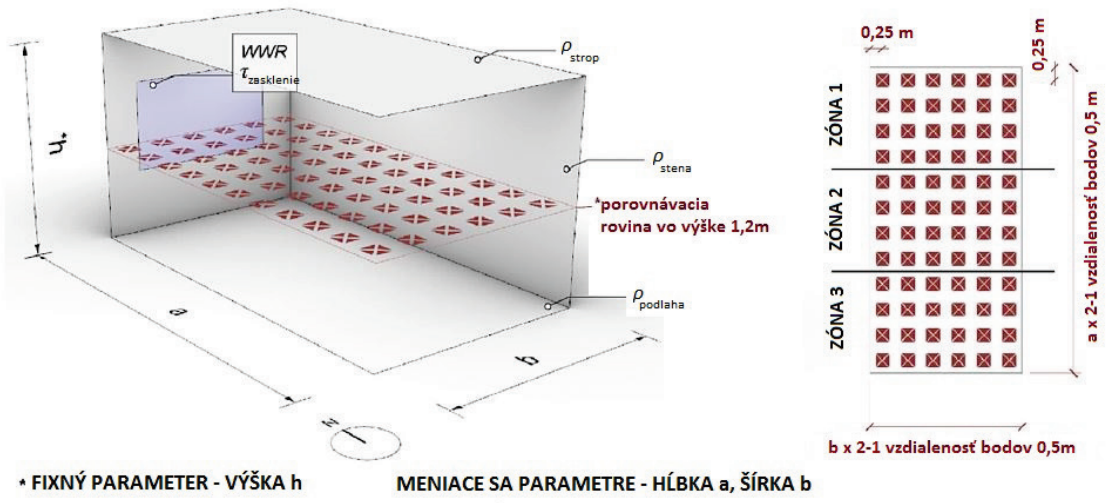

Obr. 3 Príklad geometrického modelu miestnosti so zadávanými parametrami a smermi pohl'adov v meraných bodoch [26].

Modelovaná kancelária má jedno okno orientované na sever s pevnou výškou parapetu 0,85 m. Parameter WWR sa pri simulacií pohyboval v rozmedzí 20 - $40 \%$, pôdorysné rozmery miestnosti a, b sa pohybovali v rozmedzí 3 až $8 \mathrm{~m}$. Priestor kancelárie bol po híbke rozdelený rovnomerne do 3 zón. Vyhodnocovanie výsledkov prebiehalo na rastri bodov vo vzájomnej vzdialenosti $0,5 \mathrm{~m}$ a $0,25 \mathrm{~m}$ od steny na horizontálnej porovnávacej rovine vo výške $1,2 \mathrm{~m}$ od podlahy. Pre každý porovnávací bod boli simulované 4 smery pohl'adu v azimute $0^{\circ}, 90^{\circ}, 180^{\circ}$ a $270^{\circ}$, pričom azimut $0^{\circ}$ zodpovedá pohl'adu orientovanému k oknu. Vonkajšie spektrálne svetelné podmienky boli generované pomocou softvéru Libradtran [29], ktorý je implementovaný v programe Alfa. Pre simuláciu bol použitý typ rovnomerne zamračenej oblohy s konštantným jasom s úrovňami osvetlenosti pre 21. december (lokalita L'ubl'ana) od 8:00 do 12:00 [26] - Obr. 4. 


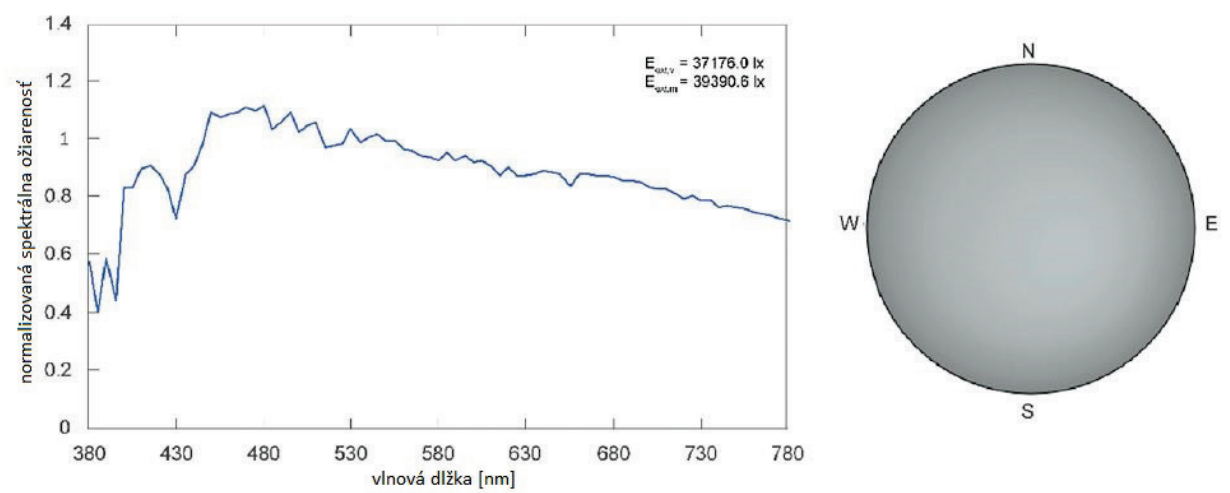

Obr. 4 Normalizovaná spektrálna ožiarenost’ rovnomerne zamračenej oblohy s konštantným jasom [26].

Na stenách, strope a podlahe interiéru boli použité materiály s difúzne odrážajúcimi matnými povrchmi. Pre ideálny sivý povrch sa odrazivost' sa menila v rozsahu od 0,1 po 0,9 , pričom vizuálna a melanopická odrazivost' boli rovnaké. Pre farebné odtiene povrchov sa odrazivost' menila v rozsahu od 0,25 po 0,75 , pričom vizuálna a melanopická odrazivost' bola rôzna - Obr. 6. Analogický prístup bol použitý aj pri výbere vlastností pre priehl'adné materiály zasklenia. Jedno zasklenie bolo z teoretického materiálu s jednotnou spektrálnou priepustnost'ou v rozsahu od 0,1 po 0,9 , pričom vizuálna a melanopická priepustnost' boli rovnaké - Obr. 5. Ďalšie zasklenia predstavovali výber zo 7 typických súčasných komerčných systémov zasklení s hodnotami priepustností od 0,302 po 0,82 , pričom vizuálna a melanopická priepustnost' bola rôzna. Okrem toho bol ešte posudzovaný prípad bez použitia zasklenia, kde sa uvažovalo $\mathrm{s} \tau \mathrm{v}=1,0$. Jednotlivé kombinácie materiálov sa neposudzovali pre všetky možné kombinácie pôdorysných rozmerov [26].

Simulované spektrálne žiarenie v modelovej kancelárií bolo v predmetnej štúdií [26] vyhodnocované pomocou 3 rôznych metodológií: vážená vizuálna osvetlenost' Ev (metodika fotopického luxu podl'a CIE, funkcia V( $\lambda)$ ), vážená melanopická osvetlenost' Em (metodika odvodená pomocou ekvivalentného melanopického luxu podl’a [12] a odporúčaní CIE, funkcia $\operatorname{sm}(\lambda)$, minimálna hodnota 150 melanopických lx (EML) najmenej 4 hodiny počas dňa podl'a WELL Building Standard) a metodika cirkadiánneho svetla CLA (spektrálna ožiarenost' podl'a [16][17][18], minimálna hodnota CS $=0,3)$.

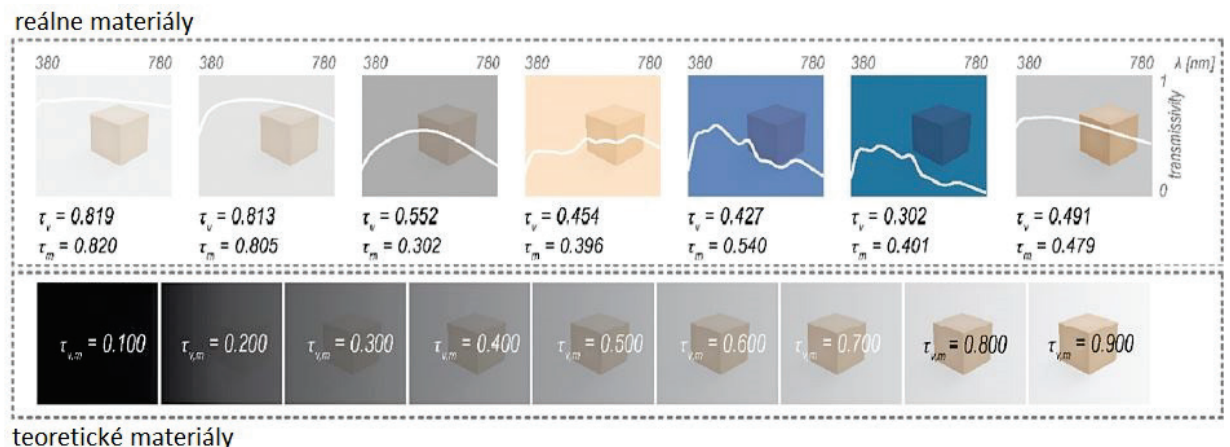

Obr. 5 Hodnoty vizuálnej a melanopickej priepustnosti zasklení [26]. 


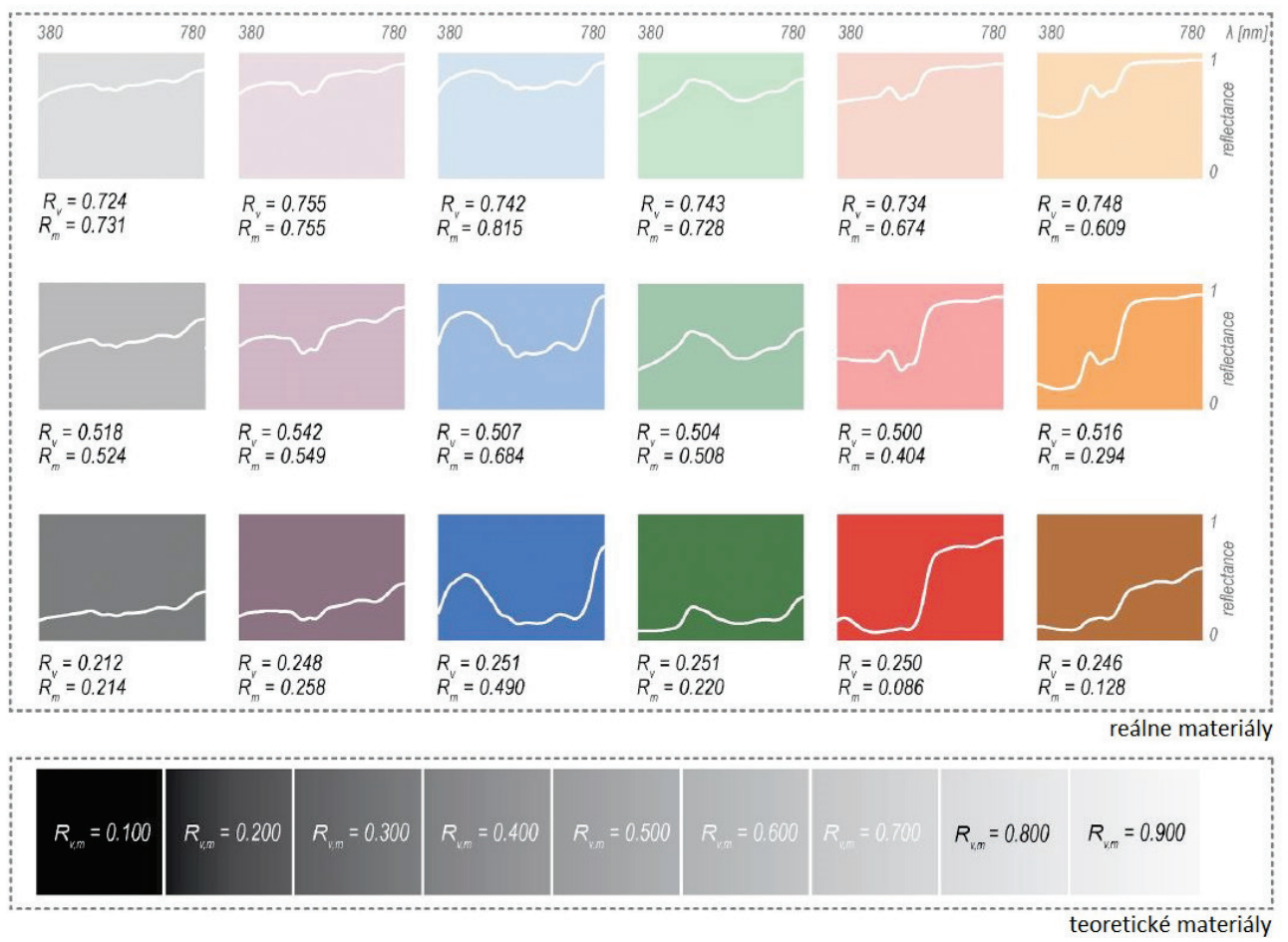

Obr. 6 Hodnoty vizuálnej a melanopickej odrazivosti vnútorných povrchov [26].

\section{HODNOTENIE POMOCOU METÓDY UŽITOČNÉHO DENNÉHO SVETLA (UDI)}

Na dosiahnutie vnútornej vizuálnej pohody je potrebné „dostatočné“ množstvo svetla t.z., že príliš vysoké alebo príliš malé množstvo svetla môže spôsobit' vizuálnu nepohodu. Z toho dôvodu bola zavedená interpretácia ročnej úrovne osvetlenosti [30] na základe reálnych údajov o počasí. Výpočet horizontálnej osvetlenosti denného svetla v každom meranom bode počas určitého časového obdobia poskytuje UDI (užitočné denné svetlo, ang. Useful Daylight Illuminance) percentuálny podiel obsadeného času, ked’úroveň osvetlenia spadá do jedného z vopred definovaných rozsahov osvetlenosti:

- úroveň osvetlenia nižšia ako adekvátne množstvo denného svetla, ktorá naznačuje, že denné svetlo nemôže byt' jediným zdrojom osvetlenia v miestnosti a pre splnenie kritérií bez vizuálneho nepohodlia je potrebné umelé osvetlenie,

- požadovaná úroveň osvetlenia - adekvátna (užitočná) úroveň,

- úroveň osvetlenia vyššia ako je primerané množstvo denného svetla, v ktorej nadmerné zásobovanie denným svetlom pravdepodobne spôsobí vizuálnu nepohodu.

Úroveň osvetlenosti považovaná za „užitočnú“ nemá určené žiadne konkrétne hranice, ale je skôr definovaná na základe konkrétnej vizuálnej požiadavky a postoja, preferencií a správanie sa pozorovatel’ov. Vo všeobecnosti sa za minimálnu hranicu považuje rozsah od 100 do 300 lx, v závislosti od minimálnych hygienických požiadaviek jednotlivých krajín na denné osvetlenie. UDI v rozsahu od 300 - 3000 lx, t.j. požadovaný rozsah na denné osvetlenie, je limitované maximálnou hornou hranicou 3000 lx, ktorú definuje neprimerané oslnenie zraku pre kancelárske priestory [14]. 

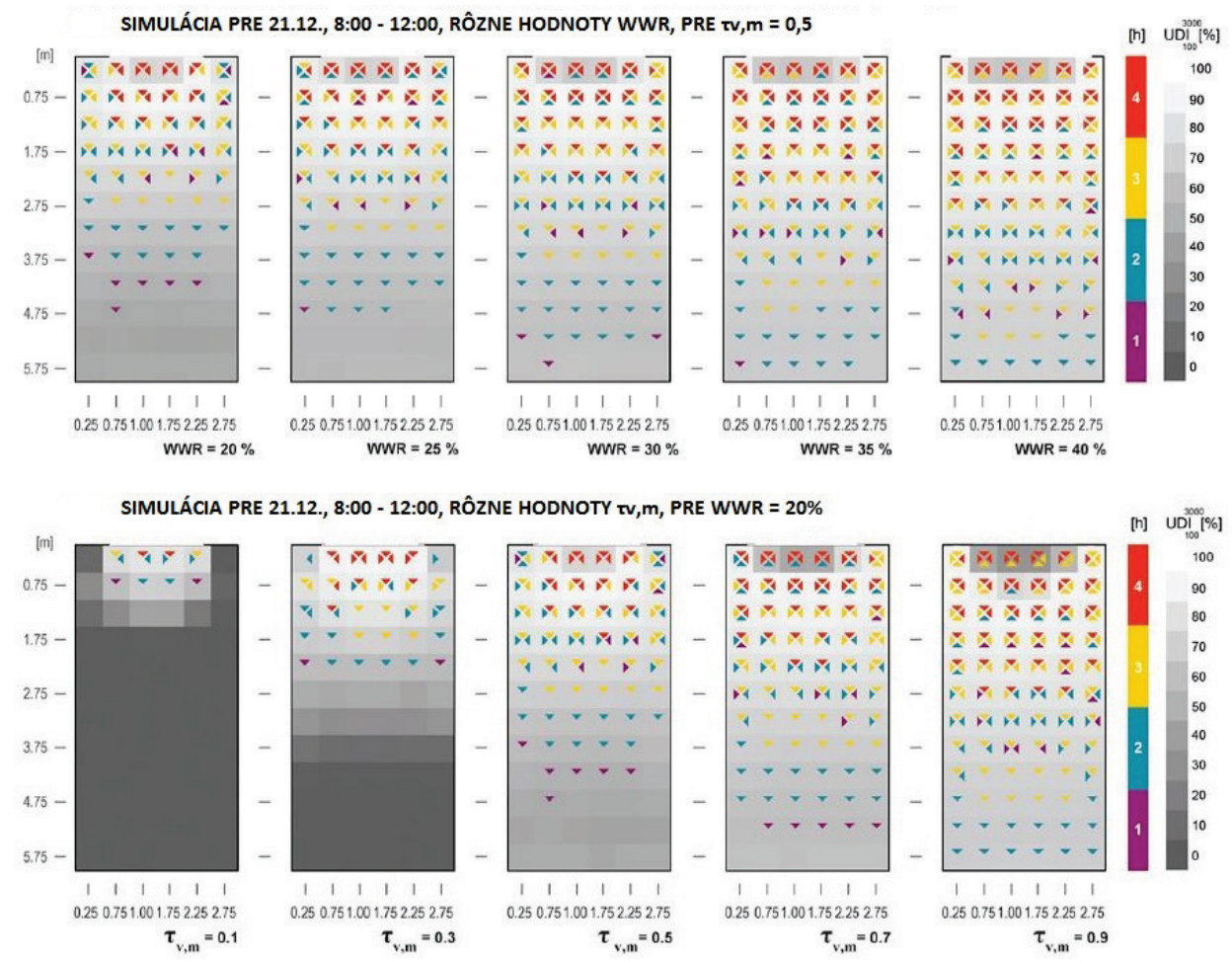

Obr. 7 Vyhodnotenie efektívnej cirkadiánnej expozície [26].

Na Obr. 7 je znázornený význam WWR, priepustnosti zasklenia $\tau$ v a odrazivosti stien $\rho v$ pri určovaní úrovní osvetleností pomocou UDI a smeru pohl'adu pozorovatel'a. Celkovo možno skonštatovat', že v danom modelovom priestore sa vyskytujú prípady s vel’mi nízkou nevizuálnou expozíciou a zároveň vysokými hodnotami UDI a prípady s vysokou nevizuálnou expozíciou a zároveň nízkymi hodnotami UDI. Táto asynchrónnost' vizuálnych a nevizuálnych charakteristík vnútorného prostredia je ovplyvnená samotnými optickými vlastnost’ami zasklenia a vnútorných povrchov stien, stropu a podlahy. Významnú úlohu pritom zohrávajú jednotlivé farebné odtiene povrchov. Napr. modrá a červená farba môžu mat’ približne rovnakú vizuálnu odrazivost' $\rho v, v=0,5$, ale ich vzájomná melanopicky vážená odrazivost' je výrazne rozdielna $\rho v, m e l=0,684$ pre modrú farbu a $\rho v, m e l=0,404$ pre červenú farbu. Rovnaký princíp funguje aj pre rôzne sfarbené zasklenia. Zasklenia sfarbené do odtieňov bronzovej farby budú mat' nižšiu melanopicky váženú priepustnost' ako zasklenia sfarbené do zelena [31]. Tento vplyv zasklenia sa zvyšuje s narastajúcim pomerom okna k stenám WWR, ked' sa môže stat', že pri úzkych miestnostiach s hodnotami WWR $>40 \%$ odrazivost' stien bude zohrávat' len minimálnu úlohu.

Zo zvyšujúcou úrovňou osvetlenosti sa tento vplyv čiastočne eliminuje, čo dokazujú hodnoty namerané v 1. tretine hĺbky miestnosti, kde prakticky skoro všetky smery pohl’adu spĺn̆ajú požiadavky na denné osvetlenie (okrem prípadov s vel'mi nízkymi hodnotami priepustností zasklenia $\tau \mathrm{v}<0,3$ ). V druhej a tretej tretine miestnosti zohrávajú výraznú úlohu optické vlastností netransparentných povrchov a dokonca v tretej tretine vyhovujú prakticky len pohl'ady smerom k oknu.

\section{ZÁVER}

Prirodzená dvojakost' optických vlastností bežných stavebných materiálov môže predstavovat' značnú prekážku pre dizajnérov pri hodnotení vizuálnych aj nevizuálnych svetelných charakteristík vnútorného prostredia. Hore rozoberaná štúdia [26] naznačuje nesúčinnost' vizuálnych a nevizuálnych charakteristík vnútorného svetelného prostredia. Materiály s rovnakými vizuálne váženými odrazivost’ami alebo priepustnost'ami môžu produkovat' 
výrazne odlišné vizuálne a nevizuálne výsledky, čo už naznačili rôzni vedci [26], [32], [33]. Podl’a môjho názoru by mal nastat' posun v stavebných predpisoch a normách k špecifikácii melanopicky vážených vlastností, najmä v prípade zasklení a povrchov vo vnútornom prostredí. V prípade plytkých miestností mala venovat' zvýšená pozornost' návrhu stavebno-fyzikálnych vlastností okien a v prípade hlbokých miestností by sa mal návrh zameriavat' skôr na optické vlastnosti povrchov stien. Na záver je potrebné zdôraznit', že vplyv všetkých zvažovaných parametrov závisí od uhla pohl'adu a híbky, čo znamená, že rozhodnutia o návrhu by sa v prvom rade mali riadit' využitím priestoru a geometrie miestnosti.

\section{Pod'akovanie}

Tento príspevok podporili výskumné projekty APVV-18-0174 a VEGA 1/0042/21.

\section{Použité zdroje}

[1] 1 FIGUEIRO, M.G. et al. The impact of daytime light exposures on sleep and mood in office workers. 2017.

[2] 2 BERSON, D.M. et al. Phototransduction by Retinal Ganglion Cells That Set the Circadian Clock. 2002.

[3] 3 BRAINARD, G.C. et al. Action Spectrum for Melatonin Regulation in Humans: Evidence for a Novel Circadian Photoreceptor. 2001.

[4] 4 WAHNSCHAFFE, A. et al. Out of the Lab and into the Bathroom: Evening Short-Term Exposure to Conventional Light Suppresses Melatonin and Increases Alertness Perception. 2013.

[5] 5 WESTLAND, S. et al. A review of the effects of colour and light on non-image function in humans Coloration Technology. 2017.

[6] 6 TERMAN, B.M. - TERMAN, J.S. Light Therapy for Seasonal and Nonseasonal Depression: Efficacy, Protocol, Safety, and Side Effects. 2005.

[7] 7 ZAZZINI, P. et al. Experimental analysis of the performance of light shelves in different geometrical configurations through the scale model approach. 2020.

[8] 8 ROBINSON, D. Residential Magnetic Fields, Light-at-Night, and Nocturnal Urinary 6Sulfatoxymelatonin Concentration in Women. 2019.

[9] 9 BROWN, M.J. - JACOBS, D.E. Residential Light and Risk for Depression and Falls: Results from the LARES Study of Eight European Cities. 2011.

[10] 10 THAPAN, K. et al. An action spectrum for melatonin suppression: evidence for a novel non-rod, noncone photoreceptor system in humans. 2001.

[11] 11 BAILES, H.J. et al. Human melanopsin forms a pigment maximally sensitive to blue light. 2013.

[12] 12 LUCAS, R.J. et al. Measuring and using light in the melanopsin age. 2014.

[13] xx13 CIE S 026/E:2018 CIE System for Metrology of Optical Radiation for ipRGC-Influenced Responses to Light 2018.

[14] 14 SALAMATI, M. et al. Daylight performance analysis of TiO2@W-VO2 thermochromic smart glazing in office buildings. 2020.

[15] 15 SCHLANGEN, L. Human Centric Lighting needs new quantities for light intensity. 2016.

[16] 16 REA M., FIGUEIRO M., BIERMAN A., HAMMER R. Modelling the spectral sensitivity of the human circadian system. 2015.

[17] 17 REA, M.S. et al. A model of phototransduction by the human circadian system. 2005.

[18] $18 \mathrm{CHEN}, \mathrm{X}$. et al. Glazing type (colour and transmittance), daylighting, and human performances at a workspace. 2019.

[19] 19 EMDE, C. et al. The Libradtran software package for radiative transfer calculations. 2016.

[20] 20 ACOSTA I. - LESLIE R. Analysis of circadian stimulus allowed by daylighting in hospital rooms. 2015.

[21] 21 MELLERIO, J. - STREET, N.C. Yellowing of the human lens: nuclear and cortical contributions. 1987.

[22] 22 KONIS, K. Field evaluation of the circadian stimulus potential of daylit and non-daylit spaces in dementia care facilities. 2018.

[23] 23 INANICI, M. et al. Spectral daylighting simulations: computing circadian light. 2015.

[24] 24 POTOČNIK, J. - KOŠIR, M. In-situ Determined Circadian and Visual Daylighting Potential of an Office. 2019.

[25] 25 POTOČNIK, J. - KOŠIR, M. Influence of commercial glazing and wall colours on the resulting nonvisual daylight conditions of an office. 2020.

[26] 26 POTOČNIK, J. - KOŠIR, M. Influence of geometrical and optical building parameters on the circadian daylighting of an office. 2021.

[27] 27 Rhino 6 [WWW document], URL, https://www.rhino3d.com/6, 2019. 
[28] 28 LLC Sollemma, Alfa - adaptive lighting for alertness [WWW document], URL, https://www.solemma.com/Alfa.html, 2020. accessed 10.30.20.

[29] 29 DIJK D. - LOCKLEY S. Functional Genomics of Sleep and Circadian Rhythm. 2013.

[30] 30 MARDALJEVIC, J. et al. Daylighting metrics: is there a relation between useful daylight illuminance and daylight glare probability? 2012.

[31] 31 HARTMAN, P. et al. Variation in internal space surface colors and its possible effect on human biological responses in daylight conditions. 2015.

[32] 32 BELLIA, L. et al. Lighting in indoor environments: Visual and non-visual effects of light sources with different spectral power distributions. 2011.

[33] $33 \mathrm{CAI}, \mathrm{W}$. et al. The impact of room surface re fl ectance on corneal illuminance and rule-of-thumb equations for circadian lighting design. 2018. 